\title{
PROFIL PROSES BERPIKIR SISWA DALAM PEMECAHAN MASALAH MATEMATIKA MATERI LUAS PERMUKAAN DAN VOLUME BANGUN RUANG KUBUS DAN BALOK DITINJAU DARI TINGKAT KEMAMPUAN BERPIKIR KREATIF DI KELAS VIII C SMP NEGERI 5 JAYAPURA.
}

\author{
Pitriana Tandililing \\ Universitas Cenderawasih \\ fitrianawill@gmail.com
}

\begin{abstract}
Abstrak. Penelitian ini merupakan penelitian deskriptif dengan menggunakan pendekatan kualitatif, yang dilakukan di SMP Negeri 5 Jayapura kelas VIIIC. Tujuan penelitian ini adalah untuk mendeskripsikan proses berpikir siswa dalam pemecahan masalah materi luas permukaan dan volume bangun ruang kubus dan balok ditinjau dari tingkat kemampuan berpikir kreatif. Proses berpikir dalam penelitian ini menggunakan proses berpikir model Wallas yang terdiri dari empat tahapan yaitu Persiapan, inkubasi, iluminasi dan verifikasi. Subjek penelitian berjumlah tiga orang dengan tingkat kemampuan berpikir kreatif yang berbeda, yaitu siswa kreatif, siswa kurang kreatif dan siswa kurang kreatif teknik pengambilan subjek menggunakan purposive Sampling. Pengambilan data dilakukan dengan teknik tes dan wawancara. Tes yang diberikan berupa tes pemecahan masalah sebanyak tiga butir soal. Berdasarkan hasil penelitian diperoleh bahwa: (1) tahap persiapan, subjek yang kreatif dapat memahami maksud dari semua soal. Subjek tersebut dapat menuliskan dan menyebutkan apa yang diketahui dan apa yang ditanya dengan menggunakan bahasanya sendiri untuk semua soal. Subjek yang kurang kreatif dapat memahami maksud dari semua soal. Namun subjek tersebut hanya dapat menuliskan dan menyebutkan apa yang diketahui dan apa yang ditanya pada beberapa soal. Subjek yang tidak kreatif tidak dapat memahami maksud dari semua soal yang diberikan. Saat akan memulai mengerjakan soal, semua subjek selalu memikirkan rumus atau konsep matematika yang sesuai dengan soal. (2) tahap inkubasi, semua subjek berusaha menemukan cara penyelesaian soal dengan mencoret-coret di kertas kosong (kertas buram). Pada tahap ini juga, semua subjek menunjukkan gerak-gerik tertentu saat mengerjakan soal. (3) tahap iluminasi, subjek yang kreatif dapat menunjukkan langkah-langkah kerja yang tepat dalam mengerjakan soal. Subjek tersebut menunjukkan ekspresi puas setelah selesai mengerjakan soal. Subjek yang kurang kreatif menunjukkan proses yang sama pada tahap iluminasi dengan subjek yang kreatif. Subjek yang tidak kreatif tidak dapat menunjukkan langkah-langkah kerja yang tepat dalam mengerjakan soal. Subjek tersebut tidak menunjukkan ekspresi puas setelah selesai mengerjakan soal. (4) tahap verifikasi, subjek yang kreatif merasa yakin dengan semua jawaban yang diberikan, subjek yang kurang kreatif merasa yakin dengan beberapa jawabannya, sedangkan subjek yang tidak kreatif tidak yakin dengan semua jawaban yang diberikan.
\end{abstract}

Kata kunci: Profil Berpikir, Kemampuan Berpikir Kreatif, Pemecahan Masalah, Luas Permukaan, Volume Kubus dan Balok.

\section{PENDAHULUAN}

Agar dapat bersaing dalam dunia kerja dan kehidupan pribadi, siswa harus memiliki kemampuan pemecahan masalah dan harus berpikir dengan kreatif. Oleh karena itu, kemampuan berpikir kreatif penting dikembangkan dalam setiap kegiatan pembelajaran. Sekolah sebagai lembaga formal pendidikan sangat berperan penting dalam menumbuhkan dan mengembangkan kemampuan berpikir kreatif siswa. Salah satu mata pelajaran yang diberikan di sekolah adalah matematika. Badan Standar Nasional Pendidikan (BSNP) (2006: 139) menyebutkan bahwa:

Mata pelajaran Matematika perlu diberikan kepada semua siswa mulai dari sekolah dasar untuk membekali siswa dengan kemampuan berpikir logis, analitis, sistematis, kritis, dan kreatif, serta kemampuan 
bekerjasama. Kompetensi tersebut diperlukan agar siswa dapat memiliki kemampuan memperoleh, mengelola, dan memanfaatkan informasi untuk bertahan hidup pada keadaan yang selalu berubah, tidak pasti, dan kompetitif.

Berdasarkan hal tersebut, bahwa salah satu tujuan dari proses pembelajaran matematika adalah untuk membekali siswa memiliki kemampuan berpikir kreatif. Pembelajaran matematika akan lebih bermakna dan menarik bagi siswa jika guru dapat menghadirkan masalah-masalah kontekstual dan realistik, yaitu masalahmasalah yang sudah dikenal dekat dengan kehidupan sehari-hari siswa. Masalah kontekstual dapat digunakan sebagai titik awal pembelajaran matematika dalam membantu siswa mengembangkan pengertian terhadap konsep matematika yang dipelajari dan juga bisa digunakan sebagai sumber aplikasi matematika. Masalah dapat diartikan suatu situasi atau pertanyaan yang dihadapi seorang individu atau kelompok ketika mereka tidak mempunyai aturan dan prosedur tertentu yang segera dapat digunakan untuk menentukan jawabannya.

Proses berpikir merupakan suatu proses yang mengkombinasikan berpikir divergen dan berpikir logis. Berpikir divergen digunakan untuk mencari ide-ide dalam menyelesaikan masalah. Sedangkan berpikir logis digunakan untuk memverifikasi ide-ide tersebut menjadi penyelesaian yang kreatif (Siswono, 2004: 4). Munandar (Siswono, 2004: 4) mengemukakan bahwa untuk mengetahui proses berpikir siswa digunakan pedoman untuk melihat proses berpikir. Pedoman yang sering digunakan adalah pedoman proses berpikir yang dikembangkan oleh Wallas. Pedoman tersebut merupakan salah satu teori yang paling umum digunakan untuk mengetahui proses berpikir. Siswono menyebutkan bahwa proses berpikir menurut Wallas terdiri dari empat tahap, yaitu: (1) persiapan; (2) inkubasi; (3) iluminasi; dan (4) verifikasi.

Silver (Siswono, 2006: 497) memberikan tiga indikator untuk menilai kemampuan berpikir kreatif siswa melalui pemecahan masalah yang meliputi kefasihan, fleksibelitas dan kebaruan. Kefasihan mengacu pada banyaknya ide-ide yang dibuat dalam merespon sebuah perintah, fleksibelitas tampak pada perubahan-perubahan pendekatan ketika merespon perintah, sedangkan kebaruan merupakan keaslian ide yang dibuat dalam merespon perintah. Tiga indikator tersebut juga merupakan tiga komponen kunci yang dinilai dalam menguji kreativitas menggunakan The Torrance Tests of Creative Thinking (TTCT) yaitu tes untuk menilai berpikir kreatif anak-anak dan orang dewasa yang dikembangkan oleh Torrance (Siswono, 2006: 496).

Penjenjangan kemampuan berpikir kreatif tersebut disebut dengan "Tingkat Kemampuan Berpikir Kreatif (TKBK)". TKBK yang dimiliki siswa dalam memecahkan dan mengajukan masalah matematika dibedakan menjadi TKBK 0 maksudnya siswa tidak kreatif, TKBK 1 maksudnya siswa kurang kreatif, TKBK 2 maksudnya siswa cukup kreatif, TKBK 3 maksudnya siswa kreatif dan TKBK 4 maksudnya siswa sangat kreatif. TKBK yang dikemukakan oleh Siswono tersebut didasari pada indikator berpikir kreatif yang dikemukakan oleh Silver. (Siswono, 2007).

Dalam upayanya untuk mengembangkan kemampuan berpikir kreatif siswa, seorang guru matematika harus dapat merancang suatu pembelajaran yang banyak melibatkan keaktifan siswa dan bersifat mengembangkan kemampuan berpikir kreatif siswa. Namun sebelum hal tersebut dilakukan, seorang guru matematika sebaiknya harus lebih dahulu mengetahui bagaimana tingkat kemampuan berpikir kreatif serta bagaimana proses berpikir siswanya. Tingkat kemampuan berpikir kreatif awal yang dimiliki siswa akan menjadi acuan dan dasar evaluasi guru apakah pembelajaran yang dirancang dan kemudian dilaksanakan dapat meningkatkan kemampuan berpikir kreatif siswa. Sedangkan proses berpikir siswa akan menjadi pedoman guru untuk merancang pembelajaran yang sesuai dengan perilaku siswa pada setiap tahapan proses berpikir. Harapannya adalah 
siswa akan merasa lebih mudah menerima materi yang diberikan guru tanpa mengurangi tingkat kemampuan berpikir kreatifnya.

Berdasarkan hasil diskusi dengan guru mata pelajaran matematika di SMP Negeri 5 Jayapura, diketahui bahwa masih banyak siswa yang kurang menunjukkan kreativitas dalam mengerjakan soal-soal matematika. Hal tersebut dapat terlihat dari hasil pekerjaan sebagian besar siswa yang cenderung hanya mengacu pada rumus-rumus matematika yang pernah dipelajari tanpa menunjukkan unsur kefasihan, fleksibelitas dan kebaruan.

Salah satu pokok bahasan dalam mata pelajaran matematika yang diajarkan di kelas VIII SMP semester II menurut kurikulum 2013 adalah materi bangun ruang sisi datar dan sisi lengkung. Pada materi bangun ruang sisi datar yang dibahas adalah unsur-unsur kubus dan balok, luas permukaan kubus dan balok serta volume kubus dan balok. Dalam kehidupan sehari-hari sering ditemukan benda-benda yang berbentuk kubus dan balok. Banyak permasalah matematika dalam kehidupan sehari-hari yang berhubungan dengan bangun ruang kubus dan balok khusunya masalah mengenai luas permukaan dan volume kubus dan balok. Dalam pembelajaran matematika, pemecahan masalah matematika pada materi luas permukaan dan volume kubus dan balok dapat digunakan guru sebagai sebagai salah satu alat untuk mengetahui tingkat kemampuan berpikir kreatif siswa.

Berdasarkan diuraikan di atas, perlu dilakukan penelitian dengan judul profil proses berpikir siswa dalam pemecahan masalah matematika pada materi luas permukaan dan volume bangun ruang kubus dan balok ditinjau dari tingkat kemampuan berpikir kreatif di kelas VIIIC SMP Negeri 5 Jayapura.

\section{TUJUAN PENELITIAN}

Tujuan dari penelitian ini adalah untuk mendeskripsikan profil proses berpikir siswa dalam pemecahan masalah matematika pada materi luas permukaaan dan volume bangun ruang kubus dan balok ditinjau dari tingkat kemampuan berpikir kreatif di kelas VIII C SMP Negeri 5 Jayapura.

\section{METODE PENELITIAN}

\section{Jenis Penelitian}

Penelitian ini merupakan penelitian deskriptif dengan menggunakan pendekatan kualitatif Penelitian ini bertujuan untuk memaparkan atau menggambarkan secara alamiah mengenai profil proses berpikir siswa dalam pemecahan masalah matematika pada materi luas permukaan dan volume bangun ruang kubus dan balok ditinjau dari tingkat kemampuan berpikir kreatif.

\section{Subjek Penelitian}

Subjek dalam penelitian ini adalah siswa kelas VIIIC. Penentuan subjek penelitian menggunakan teknik purposive sampling dengan menetapkan kriteria pemilihan subjek. Kriteria pengambilan subjek dalam penelitian ini adalah sebagai berikut: Setelah dilakukan tes pemecahan masalah, satu subjek penelitian yang mewakili kelompok TKBK-nya untuk dilakukan wawancara guna mendapatkan data mengenai proses berpikir. Pertimbangan dalam memilih subjek penelitian yang mewakili kelompok TKBK-nya didasarkan pada:

a. Siswa yang dipilih merupakan siswa yang mengikuti proses pembelajaran matematika dengan baik.

b. Siswa yang dipilih harus dapat berkomunikasi secara lisan dengan baik.

c. Siswa yang dipilih harus bersedia untuk diwawancarai.

Dasar pertimbangan pemilihan subjek tersebut dibuat agar dapat memudahkan peneliti mengumpulkan sebanyak mungkin informasi yang berkaitan dengan proses berpikir.

\section{Instrumen Penelitian}

Selain istrumen utama yaitu peneliti sendiri, istrumen bantu yang digunakan dalam penelitian ini adalah:

a. tes berupa tes pemecahan masalah matematika pada materi luas permukaan dan volume bangun ruang kubus dan balok. Tes tersebut harus dikerjakan dengan cara menguraikan langkahlangkah kerjanya dengan baik dan benar.

b. Pedoman wawancara digunakan pada saat melakukan wawancara dan dibuat sebagai 
acuan peneliti saat mengajukan pertanyaan wawancara.

\section{Deskripsi Data Penelitian}

Setelah melakukan tes, peneliti memeriksa hasil jawaban siswa untuk menentukan tingkat kemampuan berpikir kreatifnya. Dalam memeriksa jawaban siswa, peneliti mengacu pada tiga indikator berpikir kreatif yang dikemukakan oleh Silver, yaitu kefasihan, fleksibelitas, dan kebaruan. Kriteria dari masing-masing indikator berpikir kreatif tersebut adalah sebagai berikut:

a. Memenuhi indikator kefasihan jika siswa dapat memberikan jawaban benar yang beragam (berbeda ataupun tidak berbeda) sebanyak yang diminta pada soal dengan menggunakan langkah-langkah kerja yang tepat.

b. Memenuhi indikator fleksibelitas jika siswa dapat memberikan sekurangkurangnya satu jawaban benar dengan menggunakan lebih dari satu cara kerja dan langkah-langkah kerjanya tepat.

Memenuhi indikator kebaruan jika siswa dapat memberikan jawaban benar yang beragam berbeda sebanyak yang diminta pada soal. Jawaban tersebut menggunakan cara kerja yang lazim digunakan oleh siswa, dengan menggunakan langkah-langkah kerja yang tepat. Jawaban tersebut juga dapat memberikan jawaban yang beragam (berbeda ataupun tidak berbeda) sebanyak yang diminta pada soal dengan menggunakan cara kerja yang tidak lazim digunakan oleh siswa. Jawaban ini juga harus menggunakan langkah-langkah kerja yang tepat, atau memberikan sekurang-kurangnya satu jawaban benar yang tidak dapat diberikan oleh siswa lainnya. Jawaban yang beragam berbeda dari indikator berpikir kreatif adalah seluruh jawaban yang diberikan siswa yang tidak difokuskan pada satu jenis bilangan tertentu dan tidak menunjukkan pola tertentu.

Ditinjau dari indikator berpikir kreatif, menurut Siswono (2007) terdapat lima Tingkat Kemampuan Berpikir Kreatif (TKBK) siswa menurut Siswono, yaitu TKBK 0 maksudnya siswa tidak kreatif, TKBK 1 maksudnya siswa kurang kreatif, TKBK 2 maksudnya siswa cukup kreatif,
TKBK 3 maksudnya siswa kreatif, dan TKBK 4 maksudnya siswa sangat kreatif. Selanjutnya, kriteria dari masing-masing TKBK adalah sebagai berikut:

a. Tingkat 4 (sangat kreatif)

Siswa mampu menyelesaikan suatu masalah dengan menunjukkan kebaruan, fleksibelitas dan kefasihan atau mampu menunjukkan kebaruan dan fleksibelitas.

b. Tingkat 3 (kreatif)

Siswa mampu menyelesaikan suatu masalah dengan menunjukkan kebaruan dan kefasihan atau mampu menunjukkan kefasihan dan fleksibelitas.

c. Tingkat 2 (cukup kreatif)

Siswa mampu menyelesaikan suatu masalah dengan menunjukkan kebaruan atau mampu menunjukkan fleksibelitas.

d. Tingkat 1 (kurang kreatif)

Siswa mampu menyelesaikan suatu masalah dengan menunjukkan kefasihan.

e. Tingkat 0 (tidak kreatif)

Siswa tidak mampu menunjukkan tiga aspek indikator berpikir kreatif.

Berdasarkan hasil tes yang telah dilakukan di kelas VIII C SMP Negeri 5 Jayapura, diketahui bahwa pada kelas tersebut terdapat tiga jenis TKBK. TKBK tersebut antara lain TKBK 0 maksudnya peserta tidak kreatif sebanyak 2 siswa, TKBK 1 maksudnya siswa kurang kreatif sebanyak 10 siswa, dan TKBK 3 maksudnya siswa kreatif sebanyak 18 siswa. Dari masing-masing TKBK yang ada dipilih satu siswa yang akan dijadikan sebagai subjek penelitian.

Berdasarkan hasil tes tingkat kemampuan berpikir kreatif yang telah dilakukan, diketahui bahwa terdapat tiga TKBK siswa dari lima TKBK yang ada, yaitu TKBK 0 (tidak kreatif) sebanyak 2 orang, TKBK 1 (kurang kreatif) sebanyak 10 orang, dan TKBK 3 (kreatif) sebanyak 18 orang. Tingkat kemampuan berpikir kreatif siswa kelas VIII C yang mengikuti tes disajikan dalam tabel 4.1 berikut:

Tabel 4.1.

Tingkat Kemampuan Berpikir Kreatif (TKBK) Siswa Kelas VIII C SMP Negeri 5 Jayapura 


\begin{tabular}{|l|l|l|}
\hline No & $\begin{array}{l}\text { Kode } \\
\text { Siswa }\end{array}$ & $\begin{array}{l}\text { Tingkat } \\
\text { Berpikir Kreatif (TKBK) }\end{array}$ \\
\hline 1. & CLM & Kreatif \\
\hline 2. & DFR & Kreatif \\
\hline 3. & NH & Tidak Kreatif \\
\hline 4. & DFN & Kurang Kreatif \\
\hline 5. & ET & Kurang kreatif \\
\hline 6. & IKW & Tidak Kreatif \\
\hline 7. & AAA & Kurang Kreatif \\
\hline 8. & RTM & Kreatif \\
\hline 9. & PKSA & Kreatif \\
\hline 10. & TNJ & Kurang Kreatif \\
\hline 11. & AL & Kurang Kreatif \\
\hline 12. & FAS & Kreatif \\
\hline 13. & EGRB & Kreatif \\
\hline 14. & LE & Kurang Kreatif \\
\hline 15. & KAL & Kreatif \\
\hline 16. & RLA & Kurang Kreatif \\
\hline 17. & MMMO & Kurang Kreatif \\
\hline 18. & ARTB & Kreatif \\
\hline 19. & GA & Kreatif \\
\hline 20. & AKH & Kurang Kreatif \\
\hline 21. & AJI & Kreatif \\
\hline 22. & HN & Kreatif \\
\hline 23. & HMM & Kreatif \\
\hline 24. & WY & Kreatif \\
\hline 25. & NBK & Kreatif \\
\hline 26. & SH & Kurang Kreatif \\
\hline 27. & VMT & Kreatif \\
\hline 28. & IEA & Kreatif \\
\hline 29. & BEL & Kreatif \\
\hline 30. & CDAS & Kreatif \\
\hline & & \\
\hline
\end{tabular}

Dari masing-masing TKBK tersebut, dipilih satu siswa yang akan dijadikan sebagai subjek penelitian proses berpikir siswa dalam menyelesaikan pemecahan masalah matematika pada materi luas permukaan dan volume bangun ruang kubus dan balok. Berikut ini adalah daftar siswa yang terpilih untuk menjadi subjek penelitian:

Tabel 4.2

Daftar Subjek Penelitian Proses Berpikir Siswa

\begin{tabular}{|l|l|}
\hline No. & Kode Siswa \\
\hline 1. & $\begin{array}{l}\text { PKSA } \\
\text { (Subjek 1 / Kreatif) }\end{array}$ \\
\hline 2. & $\begin{array}{l}\text { AKH } \\
\text { (Subjek 2 / Kurang Kreatif) }\end{array}$ \\
\hline 3. & $\begin{array}{l}\text { IKW } \\
\text { (Subjek 3 / Tidak Kreatif) }\end{array}$ \\
\hline
\end{tabular}

\section{HASIL DAN PEMBAHASAN}

Profil proses berpikir subjek dalam menyelesaikan pemecahan masalah matematika ditinjau dari tingkat kemampuan berpikir kreatifnya adalah sebagai berikut:

\section{a. Tahap Persiapan}

Pada tahap persiapan, subjek yang kreatif mendapatkan informasi yang cukup untuk menyelesaikan soal. Subjek tersebut dapat memahami maksud dari semua soal yang diberikan dengan baik. Subjek yang kreatif dapat menuliskan serta menyebutkan apa yang diketahui dan apa yang ditanya dengan menggunakan bahasanya sendiri. Saat akan memulai mengerjakan soal, subjek yang kreatif memulainya dengan cara memikirkan rumus atau konsep matematika yang sesuai dengan soal yang diberikan. Subjek merasa bahwa sebelumnya sudah pernah mengerjakan soal yang serupa dengan soal yang diberikan. Dengan demikian, subjek tersebut telah mendapatkan beberapa informasi yang berkaitan dengan soal tes.

Pada tahap persiapan, subjek yang kurang kreatif mendapatkan informasi yang cukup untuk menyelesaikan soal. Subjek tersebut dapat memahami ketiga soal tes yang diberikan. Untuk soal nomor 1 dan nomor 3, subjek dapat menuliskan dan menyebutkan apa yang diketahui dan apa yang ditanya dengan menggunakan bahasanya sendiri. Untuk soal nomor 2, subjek menuliskan serta menyebutkannya dengan menggunakan bahasa soal. Saat akan memulai mengerjakan soal, subjek yang kurang kreatif tersebut memulainya dengan memikirkan cara kerja dan berusaha mengingat rumus yang sesuai dengan soal yang diberikan. Subjek merasa bahwa sebelumnya pernah mengerjakan soal yang serupa dengan beberapa soal tes yang telah diberikan. Dengan demikian, subjek tersebut telah mendapatkan beberapa informasi yang berkaitan dengan soal tes.

Sedangkan pada tahap persiapan untuk subjek yang tidak kreatif, subjek tersebut tidak berhasil mendapatkan informasi yang cukup untuk menyelesaikan soal. Subjek tidak dapat memahami maksud dari semua soal yang diberikan. Akibatnya, subjek merasa kesulitan dalam merencanakan langkahlangkah yang tepat untuk menyelesaikan soal. Saat akan memulai mengerjakan soal, subjek yang tidak kreatif selalu berusaha mengingat atau memikirkan rumus yang sesuai dengan soal yang diberikan. Subjek yang tidak kreatif merasa bahwa sebelumnya subjek pernah mengerjakan soal yang serupa dengan beberapa soal tes. Dengan demikian, subjek tersebut telah mendapatkan beberapa informasi yang berkaitan dengan soal tes.

Berdasarkan uraian mengenai tahap persiapan untuk subjek yang kreatif, kurang kreatif dan tidak kreatif, maka dapat diketahui bmahwa semua subjek harus mendapatkan 
sebanyak mungkin informasi. Informasi yang dimaksud adalah berkaitan dengan soal yang diberikan dan konsep matematika yang berhubungan, sehingga dapat mengerjakan soal dengan tepat. Hal tersebut sesuai dengan apa yang dikemukakan oleh Ningsih (Luviyandari, 2014: 33), bahwa pada tahap persiapan dalam proses berpikir kreatif, pikiran harus mendapatkan sebanyak mungkin informasi yang sesuai dengan masalah yang sedang dihadapinya. Selain itu, semua subjek selalu berusaha membuat usaha awal untuk mengerjakan soal. Usaha awal tersebut ditunjukkan dengan mengingat atau memikirkan rumus yang sesuai dengan soal. Hal tersebut sesuai dengan yang dikemukakan oleh Solso (2008: 444), yang mengatakan bahwa tahap persiapan adalah tahap merumuskan suatu masalah dan membuat usaha awal untuk memecahkannya.

\section{b. Tahap Inkubasi}

Pada tahap ini akan dilihat hal-hal yang dilakukan subjek pada saat mengalami kesulitan dalam mengerjakan soal. Saat subjek yang kreatif mengalami kesulitan dalam mengerjakan soal, subjek tersebut berusaha menemukan cara menyelesaikan dengan mencoret-coret di kertas kosong (kertas buram). Subjek tersebut juga menunjukkan gerak-gerik seperti, tersenyum ketika salah mengerjakan soal, memainkan ballpointnya, meletakkan tangan di dahi, menatap lembar jawaban, menggaruk-garuk kepala, meletakkan ballpoint di dagu, melihat ke sisi kiri, sisi kanan, dan menatap ke atas.

Pada saat subjek yang kurang kreatif mengalami kesulitan dalam mengerjakan soal, subjek tersebut berusaha menemukan cara menyelesaikan dengan mencoret-coret di kertas kosong (kertas buram). Subjek yang kurang kreatif juga menunjukkan gerak-gerik seperti, tersenyum ketika salah mengerjakan soal, menggaruk-garuk kepala, menarik napas, mengorek-ngorek kuku, menggoyanggoyangkan kertas soal, menempelkan tangan di dagu, dan berpikir sambil menatap ke sisi kirinya, sisi kanannya dan menatap ke atas.

Sedangkan saat subjek yang tidak kreatif mengalami kesulitan dalam mengerjakan soal, subjek tersebut berusaha menemukan cara menyelesaikan dengan mencoret-coret di kertas kosong (kertas buram). Subjek tersebut juga menunjukkan gerak-gerik seperti, diam sejenak, menarik napas, merunduk, merenung/memikirkan sesuatu sambil menatap lembar jawaban dan meletakkan tangan di dagu.

Berdasarkan uraian mengenai tahap inkubasi untuk subjek yang kreatif, kurang kreatif dan tidak kreatif , maka dapat diketahui bahwa semua subjek selalu membuat gerak-gerik tertentu saat mengalami kesulitan mengerjakan soal. Gerak-gerik subjek tersebut menggambarkan adanya pengalihan perhatian di saat pikiran sedang beristirahat untuk mengerjakan soal. Subjek terlihat seperti ingin melepaskan sejenak beban dalam pikirannya karena sempat mengalami kesulitan saat mengerjakan soal. Walaupun demikian, subjek beberapa kali terlihat menunjukkan gerak-gerik sambil berpikir dengan santai. Hal tersebut sesuai dengan yang dikemukakan oleh Solso (2008: 444), bahwa tahap inkubasi adalah tahap dimana tidak ada usaha yang dilakukan secara langsung untuk memecahkan masalah dan perhatian dialihkan sejenak pada hal lainnya. Selain itu, tahap inkubasi yang dilakukan semua subjek tersebut juga sesuai dengan yang dikemukakan oleh Munandar (Luviyandari, 2014: 34), bahwa tahap inkubasi merupakan tahap dimana individu seakan-akan melepaskan diri untuk sementara dari masalah tersebut, dalam arti bahwa dia tidak memikirkan masalahnya secara sadar tetapi mengeramnya dalam alam pra-sadar.

\section{c. Tahap Iluminasi}

Pada tahap iluminasi, subjek yang kreatif dapat menunjukkan langkah-langkah yang tepat dalam mengerjakan soal. Subjek tersebut merasa bahwa ada soal yang dapat dikerjakan dengan menggunakan cara lain selain cara-cara yang telah digunakannya. Akan tetapi subjek yang kreatif tidak dapat menggunakan cara-cara lain tersebut. Setelah selesai mengerjakan soal, subjek yang kreatif menunjukkan ekspresi tersenyum lega. Ekspresi tersebut seperti layaknya ekspresi yang ditunjukkan oleh seseorang yang merasa telah berhasil menyelesaikan suatu masalah. 
Pada tahap iluminasi, subjek yang kurang kreatif dapat menunjukkan langkahlangkah yang tepat dalam mengerjakan soal. Subjek tersebut merasa bahwa ada soal yang dapat dikerjakan dengan menggunakan cara lain selain cara-cara yang telah digunakannya. Akan tetapi subjek tersebut tidak dapat menggunakan cara-cara lain tersebut. Pada umumnya, setelah subjek yang kurang kreatif selesai mengerjakan soal, subjek tersebut menunjukkan ekspresi tersenyum lega seperti layaknya ekspresi yang ditunjukkan oleh seseorang yang merasa telah berhasil menyelesaikan suatu masalah.

Sedangkan pada tahap iluminasi subjek yang tidak kreatif, subjek tidak dapat menunjukkan langkah-langkah yang tepat dalam mengerjakan soal. Subjek tersebut merasa bahwa ada cara lain yang dapat digunakan untuk mengerjakan soal tes selain cara-cara yang telah digunakannya. Akan tetapi subjek tersebut tidak dapat menggunakan cara-cara lain tersebut. Setelah selesai mengerjakan soal, subjek yang tidak kreatif tidak menunjukkan ekspresi puas seperti layakanya ekspresi yang ditunjukkan oleh seseorang yang merasa telah berhasil menyelesaikan suatu masalah.

Berdasarkan uraian mengenai tahap iluminasi untuk subjek yang kreatif, kurang kreatif dan tidak kreatif, maka dapat diketahui bahwa tahapan iluminasi yang dilewati semua subjek bergantung pada pemahamannya mengenai soal yang dikerjakan. Pada tahap ini, semua subjek merasa telah menemukan cara yang tepat untuk menyelesaikan soal yang diberikan. Hal tersebut ditunjukkan melalui langkah-langkah kerja dan jawaban yang dituliskan oleh masing-masing subjek. Hal ini sesuai dengan yang dikemukakan oleh Solso (2008: 446), bahwa tahap iluminasi adalah tahap dimana jalan terang menuju permasalahan mulai terbuka.

Dari tahap iluminasi diatas juga, diketahui bahwa subjek yang kreatif dan kurang kreatif merasa telah memahami soal dengan menunjukkan ekspresi tersenyum lega setelah selesai mengerjakan soal. Sedangkan, subjek yang tidak kreatif merasa belum memahami soal dan tidak menunjukkan ekspresi kelegaan setelah selesai mengerjakan soal. Hal ini sesuai dengan yang dikemukakan oleh Solso (2008: 446) , bahwa pada tahap iluminasi seseorang akan merasakan sensasi kegembiraaan yang luar biasa karena pemahaman meningkat, semua ide muncul, dan ide-ide tersebut saling melengkapi satu sama lain untuk menyelesaikan permasalahan. Dengan demikian, sensasi kegembiraan hanya dialami oleh subjek yang merasa telah mendapatkan pemahaman yang sangat mendalam mengenai soal yang dikerjakan.

\section{d. Tahap Verifikasi}

Pada tahap verifikasi subjek yang kreatif, subjek tersebut merasa yakin dengan semua jawaban yang diberikan. Pada tahap verifikasi subjek yang kurang kreatif, subjek merasa sangat yakin untuk soal nomor 1, merasa tidak yakin untuk soal nomor 2 dan merasa yakin untuk soal nomor 3. Pada tahap verifikasi subjek yang tidak kreatif, subjek merasa tidak yakin dengan semua jawaban yang telah diberikan karena tidak memahami maksud soal tersebut. Subjek yang kreatif, kurang kreatif dan tidak kreatif tidak mencoba menggunakan cara yang lain untuk menemukan jawabannya.

Berdasarkan uraian di atas, pernyataan yakin atau tidak yakin dari subjek menunjukkan bahwa subjek tersebut telah berusaha melihat kembali apakah hasil pekerjaanya berhasil sesuai dengan syaratsyarat yang terdapat di soal. Hal ini sesuai dengan yang dikemukakan oleh Solso (2008: 446), bahwa tahap verifikasi pada umumnya lebih singkat daripada tahap-tahap sebelumnya, karena pada tahap ini hanya menguji dan menunjau kembali hasil perhitungan seseorang, atau dapat juga untuk melihat apakah penemuannya berhasil.

Profil proses berpikir yang telah diuraikan sebelumnya dapat disajikan dalam bentuk tabel sebagai berikut: 
Tabel 4.3. Profil Proses Berpikir Siswa dalam Pemecahan Masalah Matematika Ditinjau dari Tingkat Kemampuan Berpikir Kreatifnya

\begin{tabular}{|c|c|c|c|}
\hline \multirow{2}{*}{$\begin{array}{l}\text { Jenis Tahapan dan } \\
\text { Jenis Aktivitas }\end{array}$} & \multicolumn{3}{|l|}{ Subjek } \\
\hline & Kreatif & $\begin{array}{l}\text { Kurang } \\
\text { Kreatif }\end{array}$ & $\begin{array}{l}\text { Tidak } \\
\text { Kreatif }\end{array}$ \\
\hline \multicolumn{4}{|l|}{$\begin{array}{l}\text { 1. Tahap } \\
\text { Persiapan }\end{array}$} \\
\hline $\begin{array}{l}\text { Memahami } \\
\text { maksud dari } \\
\text { semua soal. }\end{array}$ & $\sqrt{ }$ & $\sqrt{ }$ & - \\
\hline $\begin{array}{l}\text { Tidak memahami } \\
\text { maksud dari } \\
\text { semua soal. }\end{array}$ & - & - & $\sqrt{ }$ \\
\hline $\begin{array}{l}\text { Menuliskan dan } \\
\text { menyebutkan apa } \\
\text { yang diketahui } \\
\text { dan apa yang } \\
\text { ditanya dengan } \\
\text { menggunakan } \\
\text { bahasa sendiri. }\end{array}$ & $\sqrt{ }$ & $\sqrt{ }$ & - \\
\hline $\begin{array}{l}\text { Memikirkan } \\
\text { rumus atau } \\
\text { konsep } \\
\text { matematika yang } \\
\text { sesuai dengan } \\
\text { soal. }\end{array}$ & $\sqrt{ }$ & $\sqrt{ }$ & $\sqrt{ }$ \\
\hline \multicolumn{4}{|l|}{$\begin{array}{ll}\text { 2. } & \text { Tahap } \\
\text { Inkubasi }\end{array}$} \\
\hline $\begin{array}{l}\text { Berusaha } \\
\text { menemukan cara } \\
\text { menyelesaikan } \\
\text { dengan mencoret- } \\
\text { coret di kertas } \\
\text { kosong (kertas } \\
\text { buram) }\end{array}$ & $\sqrt{ }$ & & $\sqrt{ }$ \\
\hline $\begin{array}{l}\text { Menunjukkan } \\
\text { gerak-gerik } \\
\text { tertentu saat } \\
\text { mengalami } \\
\text { kesulitan } \\
\text { menyelesaikan } \\
\text { soal. }\end{array}$ & $\sqrt{ }$ & & $\sqrt{ }$ \\
\hline \multicolumn{4}{|l|}{$\begin{array}{ll}\text { 3. } & \text { Tahap } \\
\text { Iluminasi }\end{array}$} \\
\hline $\begin{array}{l}\text { Menunjukkan } \\
\text { langkah-langkah } \\
\text { kerja yang tepat } \\
\text { dalam } \\
\text { mengerjakan soal. }\end{array}$ & $\sqrt{ }$ & & - \\
\hline \begin{tabular}{l}
\multicolumn{3}{l}{ Menunjukkan } \\
ekspresi puas \\
setelah selesai \\
mengerjakan soal.
\end{tabular} & $\sqrt{ }$ & & - \\
\hline \multicolumn{4}{|l|}{$\begin{array}{l}\text { 4. Tahap } \\
\text { Verifikasi }\end{array}$} \\
\hline $\begin{array}{lr}\text { Merasa } & \text { yakin } \\
\text { dengan } & \text { semua } \\
\text { jawaban. } & \\
\end{array}$ & $\sqrt{ }$ & & - \\
\hline
\end{tabular}

\begin{tabular}{|l|l|l|l|}
\hline $\begin{array}{l}\text { Merasa yakin } \\
\text { dengan beberapa } \\
\text { jawaban. }\end{array}$ & - & $\sqrt{ }$ & - \\
\hline $\begin{array}{l}\text { Merasa tidak } \\
\text { yakin dengan } \\
\text { semua jawaban } \\
\text { yang diberikan. }\end{array}$ & - & - & $\sqrt{ }$ \\
\hline $\begin{array}{l}\text { Mencoba } \\
\text { menggunakan } \\
\text { cara lain untuk } \\
\text { menemukan }\end{array}$ & - & - & - \\
jawaban yang \\
lainnya.
\end{tabular}

\section{SIMPULAN}

Berdasarkan tujuan penelitian dan hasil pembahasan penelitian yang telah diuraikan pada bab sebelumnya, maka dapat disusun simpulan tentang profil proses berpikir dalam pemecahan masalah ditinjau dari tingkat kemampuan berpikir kreatif sebagai berikut:

a. Tahap Persiapan

Pada tahap persiapan, subjek yang kreatif memahami maksud dari semua soal yang diberikan. Subjek tersebut mampu menuliskan serta menyebutkan apa yang diketahui dan apa yang ditanya dengan menggunakan bahasanya sendiri untuk semua soal yang diberikan. Subjek yang kurang kreatif memahami maksud dari semua soal. Subjek tersebut mampu menuliskan serta menyebutkan apa yang diketahui dan apa yang ditanya dengan menggunakan bahasanya sendiri untuk beberapa soal yang diberikan. Subjek yang tidak kreatif tidak mampu memahami maksud dari semua soal. Saat akan memulai mengerjakan soal, semua subjek selalu memikirkan rumus atau konsep matematika yang sesuai dengan soal.

b. Tahap Inkubasi

Pada tahap inkubasi, semua subjek berusaha menemukan cara penyelesaian soal dengan mencoret-coret di kertas kosong (kertas buram). Semua subjek juga menunjukkan gerak-gerik tertentu saat mengerjakan soal. Subjek yang kreatif menunjukkan gerak-gerik tersenyum ketika salah mengerjakan soal, memainkan ballpointnya, meletakkan tangan di dahi, menatap lembar jawaban, menggarukgaruk kepala, meletakkan ballpoint di 
dagu, melihat ke sisi kiri, sisi kanan, dan menatap ke atas. Subjek yang kurang kreatif menunjukkan gerak-gerik tersenyum ketika salah mengerjakan soal, menggaruk-garuk kepala, menarik napas, mengorek-ngorek kuku, menggoyanggoyangkan kertas soal, menempelkan tangan di dagu, berpikir sambil menatap ke sisi kirinya, sisi kanannya dan menatap ke atas. Subjek yang tidak kreatif menunjukkan gerak-gerik diam sejenak, menarik napas, merunduk, merenung sesuatu sambil menatap lembar jawaban dan meletakkan tangan di dagu.

c. Tahap Iluminasi

Pada tahap iluminasi, subjek yang kreatif dapat menunjukkan langkah-langkah kerja yang tepat dalam mengerjakan soal. Subjek yang kreatif juga menunjukkan ekspresi puas setelah selesai mengerjakan soal. Subjek yang kurang kreatif menunjukkan proses yang sama pada tahap iluminasi dengan subjek yang kreatif. Subjek yang tidak kreatif, tidak dapat menunjukkan langkah-langkah kerja yang tepat dalam mengerjakan soal. Subjek yang tidak kreatif tidak menunjukkan ekspresi puas setelah selesai mengerjakan soal.

d. Tahap Verifikasi

Pada tahap verifikasi, subjek yang kreatif merasa yakin dengan semua jawaban yang diberikan. Subjek yang kurang kreatif merasa yakin dengan beberapa jawabannya. Sedangkan subjek yang tidak kreatif, tidak yakin dengan semua jawabannya. Pada tahap ini, semua subjek tidak mencoba menggunakan cara lain untuk menemukan jawaban yang lainnya.

\section{SARAN}

Berdasarkan simpulan di atas, maka dapat diberikan saran sebagai berikut:

a. Bagi sekolah

Dengan memperhatikan pada tingkat kemampuan berpikir kreatif dan proses berpikir siswa, sekolah hendaknya menyediakan semua fasilitas yang dibutuhkan guru dan siswa dalam kegiatan pembelajaran matematika agar dapat terjadi peningkatan pada tingkat kemampuan berpikir kreatif siswa.

\section{b. Bagi guru matematika}

Dengan mengetahui proses berpikir siswa, guru matematika dapat memperbanyak menggunakan metode-metode mengajar yang dapat menunjang untuk meningkatkan kemampuan berpikir siswa. Salah satu metode yang dapat digunakan untuk mengembangkan berpikir kreatif siswa yaitu dengan metode penyelesaian masalah.

c. Bagi siswa

Dalam mengembangkan proses berpikir siswa, diharapkan siswa lebih aktif dan lebih banyak berlatih menyelesaikan masalah-masalah matematika yang solusinya/cara menyelesaikan lebih dari satu. Selain itu, diharapkan siswa aktif bertanya dan berdiskusi dengan guru atau teman sejawatnya mengenai kesulitan yang dialami.

\section{DAFTAR Pustaka}

Badan Standar Nasional Pendidikan (BSNP). 2006. Standar Isi untuk Satuan Pendidikan dasar dan Menengah. Jakarta: Kementerian Pendidikan Nasional.

Luviyandari, A. 2014. Analisis Proses Berpikir Kreatif Siswa dalam Menyelesaikan Masalah Sistem Persamaan Linear Dua Variabel di Kelas X-A Madrasah Aliyah Unggulan Bandung Tulungagung. Skripsi. Tulungagung: Jurusan Tadris Matematika, Fakultas Tarbiyah dan Ilmu Keguruan, Institut Agama Islam Negeri Tulungagung.

Siswono, T. Y. E. 2007. Penjenjangan Kemampuan Berpikir Kreatif dan Identifikasi Tahap Berpikir Kreatif Siswa dalam Memecahkan dan Mengajukan Masalah Matematika. Ringkasan disertasi tahun 2007 dalam artikel ilmiah SuaraGuru.WordPress.Com.

(https://suaraguru.wordpress.com/20 09/02/02/ringkasan-disertasi-tatagyuli-eko-siswono-2/).

2006. Desain Tugas untuk
Mengidentifikasi
Berpikir Kreatif Siswar dalam
Matematika. Jurnal terakreditasi
"Pancaran Pendidikan", FKIP


Universitas Negeri Jember. Tahun XIX, No. 63, April 2006. ISSN 0852-601 X, hal 495-509. (https://tatagyes.files.wordpress.com/ 2007/10/tatag_jurnal unej.pdf).

2004. Identifikasi Proses Berpikir Kreatif Siswa dalam Pengajuan Masalah (Problem Posing) Matematika Berpandu dengan Model Wallas dan Creative Problem Solving (CPS). Buletin Pendidikan Matematika Volume 6 Nomor 2, Oktober 2004. Prodi Pend. Mat. FKIP UNPATTI Ambon. ISSN: 1412-2278.

(https://tatagyes.files.wordpress.com/ 2009/11/paper04 wallascps1.pdf).

Solso, R. L. 2208. Psikologi Kognitif. Jakarta: Erlangga 